\title{
NATIONAL BUREAU OF STANDARDS REPORT
}

\author{
6554 \\ Lighting Modifications \\ of Two
}

Flight-Refueling Drogues for Naval Aircraft

William F. Mullis and

Wade H. Askew

\section{NBS}

U. S. DEPARTMENT OF COMMERCE NATIONAL BUREAU OF STANDARDS 


\section{THE NATIONAL BUREAU OF STANDARDS}

\section{Functions and Activities}

The functions of the National Bureau of Standards are set forth in the Act of Congress, March 3, 1901, as amended by Congress in Public Law 619, 1950. These include the development and maintenance of the national standards of measurcment and the provision of means and methods for making measurements consistent with these standards; the determination of physical constants and properties of materials; the development of methods and instruments for testing matcrials, devices, and structures; advisory services to government agencies on scientific and technical problems; invention and development of devices to serve special needs of the Government; and the development of standard practices, codes, and specifications. The work includes basic and applied research, development, engineering, instrumentation, testing, evaluation, calibration services, and various consultation and information services. Research projects are also performed for other government agencies when the work relates to and supplements the basic program of the Bureau or when the Bureau's unique competence is required. The scope of activities is suggested by the listing of divisions and sections on the inside of the back cover.

\section{Publications}

The results of the Bureau's work take the form of either actual equipment and devices or published papers. These papers appear either in the Bureau's own series of publications or in the journals of professional and scientific societies. The Bureau itself publishes three periodicals available from the Government Printing Office: The Journal of Research, published in four separate sections, presents complete scientific and technical papers; the Technical News Bulletin presents summary and preliminary reports on work in progress; and Basic Radio Propagation Predictions provides data for determining the best frequencies to use for radio communications throughout the world. There are also five series of nonperiodical publications: Monographs, Applied Mathematics Series, Handbooks, Miscellaneous Publications, and Technical Notes.

Information on the Bureau's publications can be found in NBS Circular 460, Publications of the National Bureau of Standards (\$1.25) and its Supplement (\$1.50), available from the Superintendent of Documents, Government Printing Office, Washington 25, D.C. 


\title{
NATIONAL BUREAU OF STANDARDS REPORT NBS PROJECT \\ NBS REPORT \\ $0201-20-02410$ \\ November 1959 \\ 6554
}

Lighting Modifications

of Two

Flight-Refueling Drogues for Naval Aircraft

\author{
by \\ William F. Mullis \\ Wade H. Askew \\ Photometry and Colorimetry Section \\ Optics and Metrology Division
}

Test $21 \mathrm{~N}-19 / 59$

\author{
Sponsored by \\ Lighting Section, AE-8211 \\ Bureau of Aeronautics \\ Department of the Navy \\ Washington, D. C.
}

NATIONAL BUREAU OF STAN intended for use within the Go to additional evaluation and rev listing of this Report, either in the Office of the Director, Natic however, by the Government ag to reproduce additional copies :
Approved for public release by the director of the National Institute of Standards and Technology (NIST) on October 9, 2015 gress accounting documents llly published it is subjected soduction, or open-literature $n$ is obtained in writing from ch permission is not needed, spared if that agency wishes

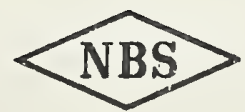

U. S. DEPARTMENT OF COMMERCE NATIONAL BUREAU OF STANDARDS 

This project was initiated after Navy field evaluation personnel had expressed dissatisfaction with existing drogue-lighting arrangements for in-flight refueling operations. Manufacturers had produced drogues with various lighting arrangements such as flashing neon lights, radioactive sources (Iso-lights), and small incandescent sources placed with filaments facing the receiver aircraft. However, none of the systems was considered entirely satisfactory by the pilots in the receiver planes.

It was requested by the Bureau of Aeronautics that the National Bureau of Standards explore means of improving the lighting characteristics of the collapsible drogue presently used by Naval aircraft. After an investigation of the various lighting systems available, it was decided that the drogues with the incandescent lights had the greatest potential for lighting improvement. All efforts were therefore directed toward the design of a satisfactory system of incandescent illumination.

\section{DESCRIPTION}

The two drogues used for this investigation were manufactured by the Dalmo Victor Co., Belmont, Calif., and were fitted with Type M-2 reception couplings by Flight Refueling Inc., Baltimore, Md. As initially received, the lighting consisted of four indicator-type light fixtures (Dialco Corp. "4-1930) fitted with Type 328 incandescent lamps and oriented so that the lamps faced the receiver aircraft during refueling operations. A photograph of one of the fixtures is shown in Figure 1. The inner surface of alternate struts of the drogues were coating with red retroreflective adhesive tape, and the remaining ones with white paint. Some receiver planes have a light which illuminates the probe tip, and the purpose of the retroreflective material was to re-direct some of this illumination back to the receiver plane. The balance of the exposed surface of each drogue, except for a black fuel coupling, had a dull gray finish. The only dissimilarity of the two drogues was in the method of powering the lights. One used four seriesconnected dry cells, and the other a wind-driven Lucas 0.36 ampere bicycle generator. The generator is driven by a small impeller, the blade tips of which protrude through the fuel reception coupling into the air stream. When received, the blades were protected, externally by two small pieces of aluminum tubing on each side of the impeller. The installation of the generator, impeller, and aluminum tubing is shown in Figures 2 and 3.

\section{TEST PROCEDURE}

Visual examination of the original lighting configuration of the drogues revealed several design features which, it was thought, could be improved. The lights were so positioned that they appeared to the pilot in the receiver aircraft as four point sources slightly separated in a dark background. Maneuvering the probe of the receiver aircraft into such a visual field is particularly difficult because of the lack of depth perception afforded. Also, the installation of the retroreflective material rendered it ineffective for redirecting the probe tip lighting to the pilot because of the large angular departure of the incident light from the normal. 

It was decided that flood lighting of the internal basket structure of the drogue, combined with retroreflective material appropriately placed, would result in an improved lighting system, and the following modifications were made.

\section{Drogue $\#$ I (Battery powered lights)}

a. The entire basket structure was painted white.

b. The inside of each light fixture was coated with white paint, and the light emitting apertures were enlarged. Figure 4 is a photograph of the modified fixture.

c. The light fixtures were oriented with lamps facing away from the receiver aircraft so that they would light the inside of the drogue.

d. Retroreflective fabric \#31 silver, manufactured by the Minnesota Mining and $\mathrm{Mfg}$. Co., was sewn to the nylon canopy around the periphery of the drogue.

Modified drogue \#1 is shown on the left in Figure \#5 along with one of the original drogues. This is a daylight photograph.

\section{Drogue \#2 (Cenerator powered lights)}

a. The entire basket structure was painted white.

b. The original light fixtures were used, but the light emitting apertures were enlarged and they were reoriented to face away from the receiver aircraft so that they illuminated the inside of the drogue.

c. Equipment which would permit a measurement of the voltage developed during flight to be read after the plane landed was designed and installed in the outer housing of the drogue. A diagram and description of the equipment are shown in Figure 6. However, this equipment has not yet been used, personnel for making the voltage measurements not being available when the flight tests were conducted.

\section{RESULTS}

Visual comparisons of the original and modified drogue, both at the National Bureau of Standards and in actual flight operations at the $\mathrm{Naval}$ Air Test Center, confirmed the expected improvement of the flood lighting arrangement. The greatest improvements resul ting from the modifications are listed below.

a. Direct light from the lamp filaments was eliminated.

b. Target conspicuity was greatly improved in that the flood lighting arrangement uniformly illuminated a large area. 

c. Since the entire interior of the drogue was illuminated significant improvement was noted in ability to determine depth of penetration of the probe.

d. The retroreflective fabric sewn to the canopy of the modified drogue was much more effective than that on the struts of the unmodified drogue.

The lighting of both modified drogues was reported by the Naval Air Test Center pilots to be satisfactory during the flight evaluations. Results of the flight tests are reported in NATC report \#I, Project No. PTR-5010 dated July 2, 1959. These results would seem to indicate two things: 1) that the special light fixtures used on drogue \#l are not required to provide sufficient illumination provided the original fixtures are properly modified and oriented, and 2) that the wind-driven generator provides sufficient power for the lamps. It should be pointed out, however, that the voltage developed by the generator in flight has not been determined and, consequently, it is not known at what voltage the lamps operated. When test flights have been made, personnel have not been available to obtain the voltage measurements after landing. Also, insufficient tests were conducted to establish definitely whether retroreflective material is actually needed. It was reported that those aircraft not, equipped with probe lights made fueling contact as easily as those that had them. This is probably because of the improved drogue lighting. Indications are, however, that should the drogue lights fail, the retroreflective material would permit refueling contact by aircraft equipped with probe lights, that is, if the lights are mounted near the line-of-sight of the pilot of the receiver plane.

It was further reported that the aerodynamic stability of the drogue had suffered slightly by the addition of the retroreflective material around the canopy. There is no ready explanation for this condition since the material was symmetrically installed except that it possibly decreased the air flow through the nylon canopy. Further tests are being made with patches of retroreflective material sewn at selected spots on the canopy rather than around its entire periphery.

During the flight tests it was found that the tubular aluminum bars (Figure 2) were not adeguate to protect the impeller wheel of the generator. Apparently when the drogue is being retracted it sometimes strikes the entrance of the housing with sufficient force to bend the bars. Stouter bars of the type similar to those shown in the upper photograph of Figure 7 were later installed on the drogue, and apparently provided adequate protection.

Later investigations were conducted to determine if the generator and flood lighting arrangement could be equally adapted to the Douglas drogue which uses a Shultz reception coupling. The installation presented no particular difficulty except that it was necessary to mount the generator and impeller wheel assembly on the casting of the reception coupling instead of on the sheet metal cover as was done with the coupling made by Flight Refueling Inc. Figure 7 shows an internal and external view of the modified coupling. The performance of this equipment was reported to have been satisfactory during flight operations, and it is considered to be a more rugged installation from a mechanical standpoint. 



\section{DISCUSSION}

It is concluded that the basic characteristics of a satisfactory drogue lighting system have been achieved but that further engineering and tests are necessary to perfect the system. For example, the paint applied to the drogue for these tests is excellent from the lighting standpoint but is relatively poor from the standpoint of wear, abrasion, stain resistance (oil and grease), and ease of cleaning. Further tests will be required to reconcile all of these features. A porcelain enamel finish or an epoxy polyomide paint appears to offer possibilities, and tests of these materials are proceeding.

Another area of possible improvement is with the generator used for powering the lights. Little is known of the characteristics or reliability of the present generator except that it apparently furnishes sufficient power. No environmental tests have been conducted to date. It is quite probable that a smaller and lighter unit suitable for this application could be designed, and it is therefore recommended that the Bureau of Aeronautics consider such a development. 


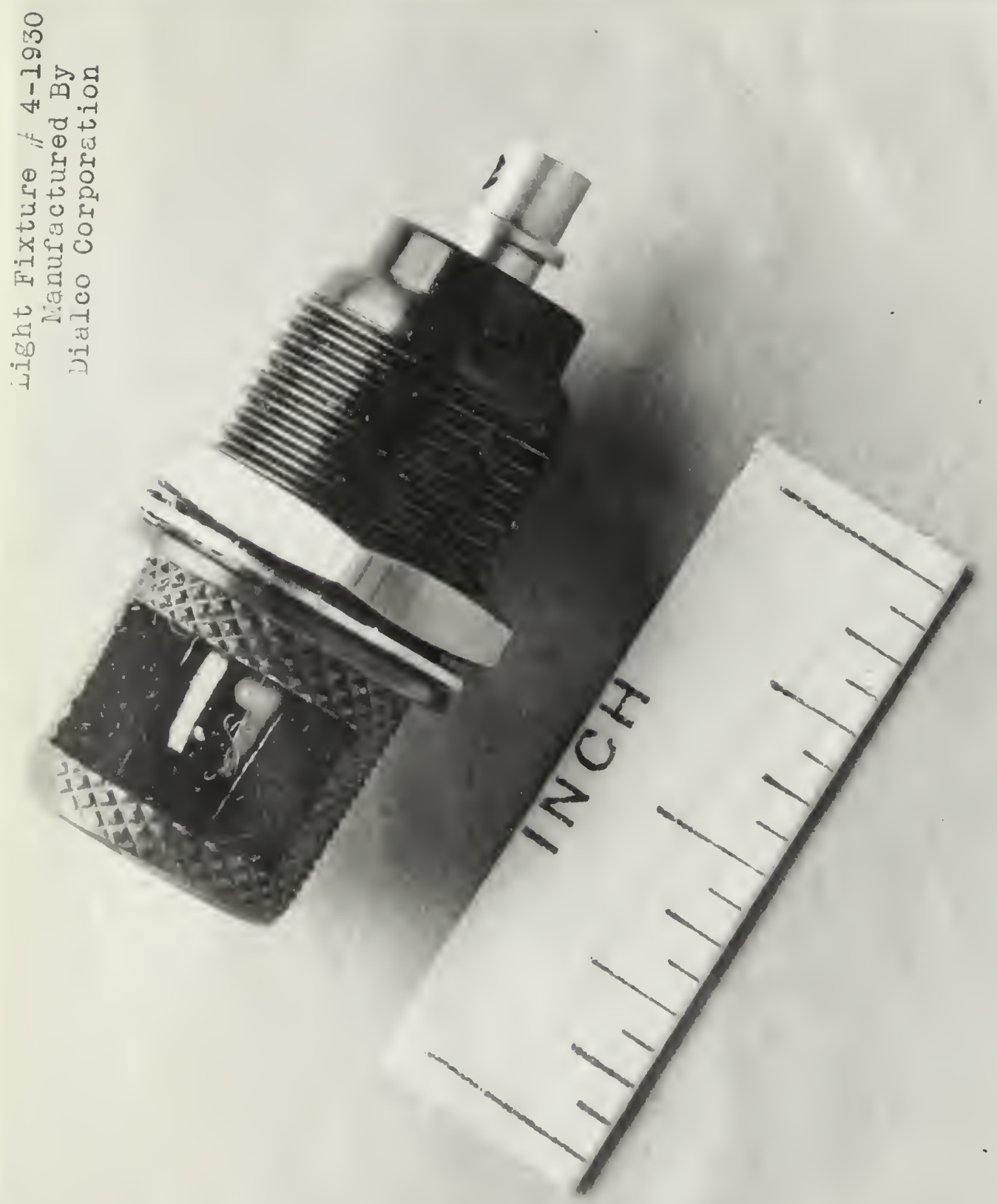

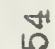

$$
\begin{aligned}
& \text { L8 } \\
& \text { 는 } \\
& + \\
& 0 \\
& \text { (1) } \\
& \text { द्य } \\
& \text { 品 }
\end{aligned}
$$





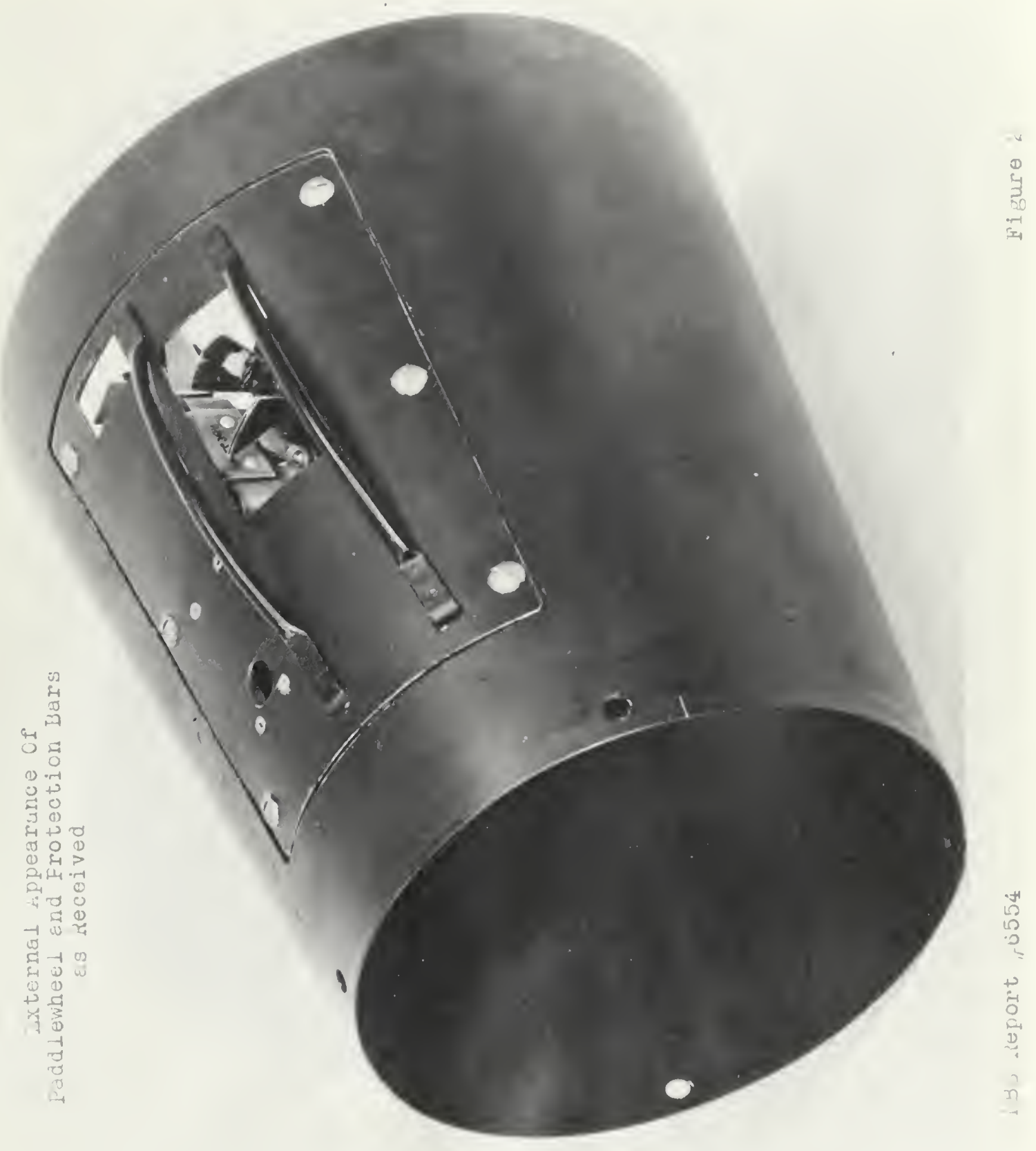





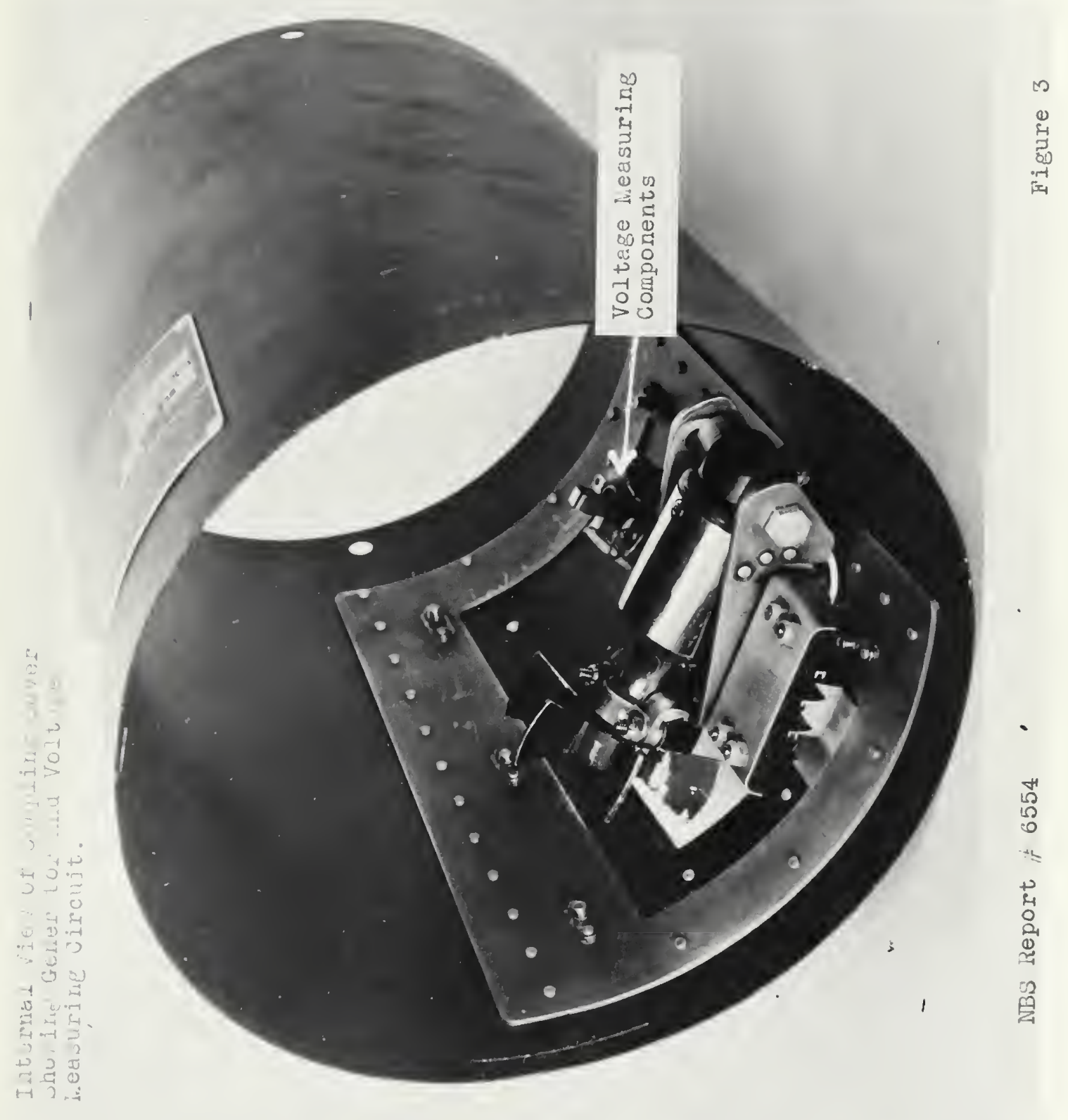





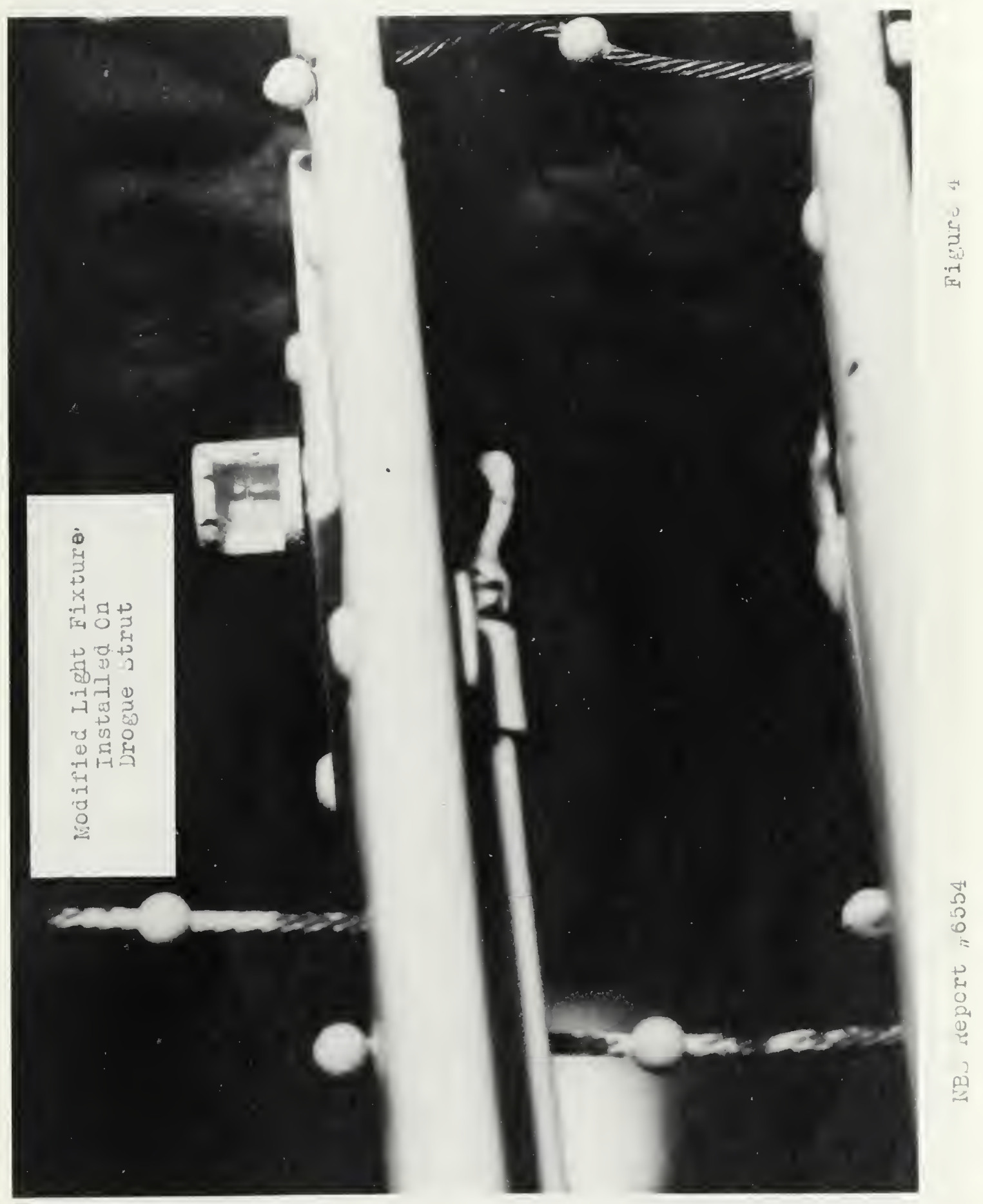





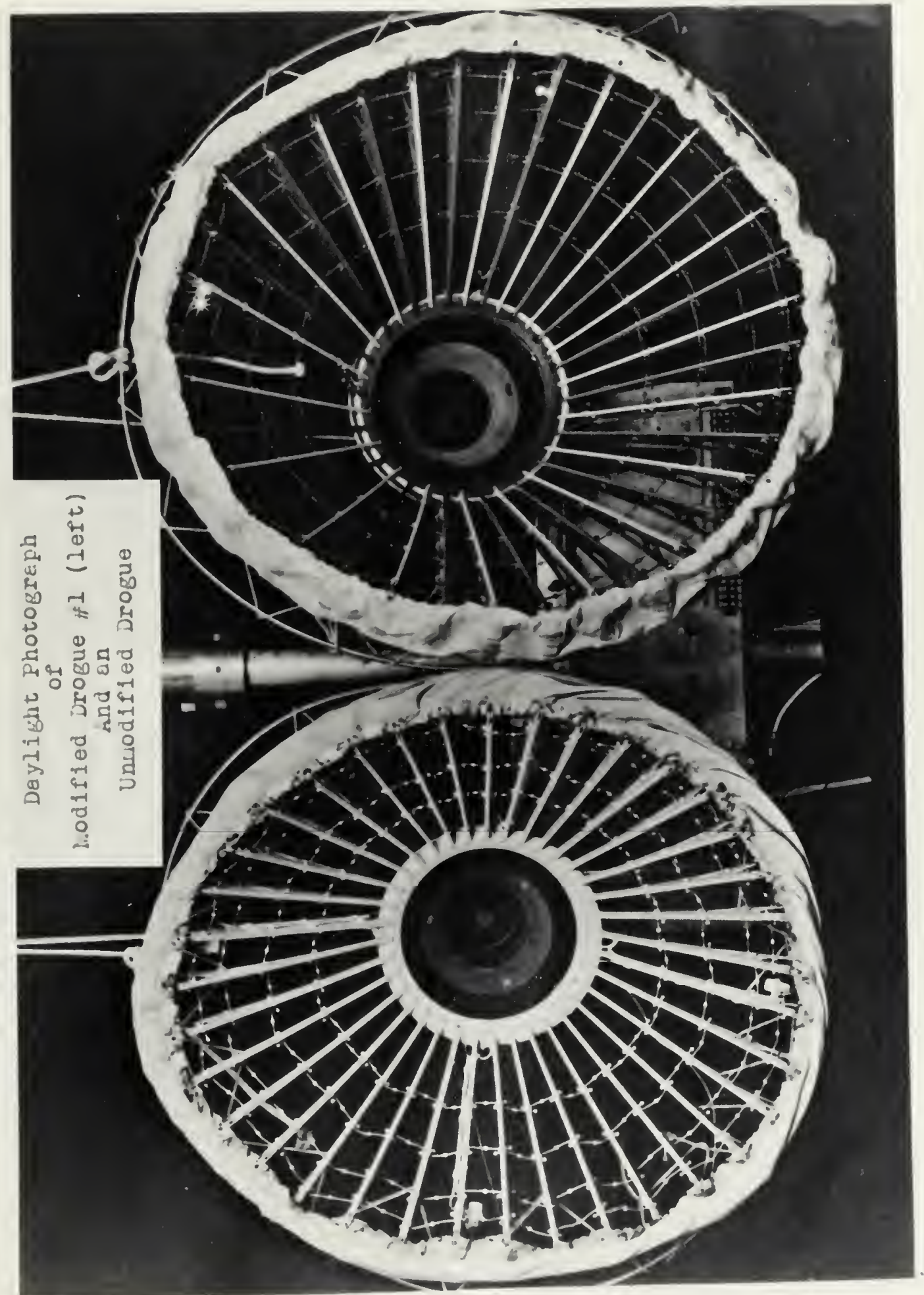



Voltage Measuring Circuit Installed

in Drogue To Permit

The Naximum Voltage Attained

in Flight

To Be Determined After The Alrcraft Lands

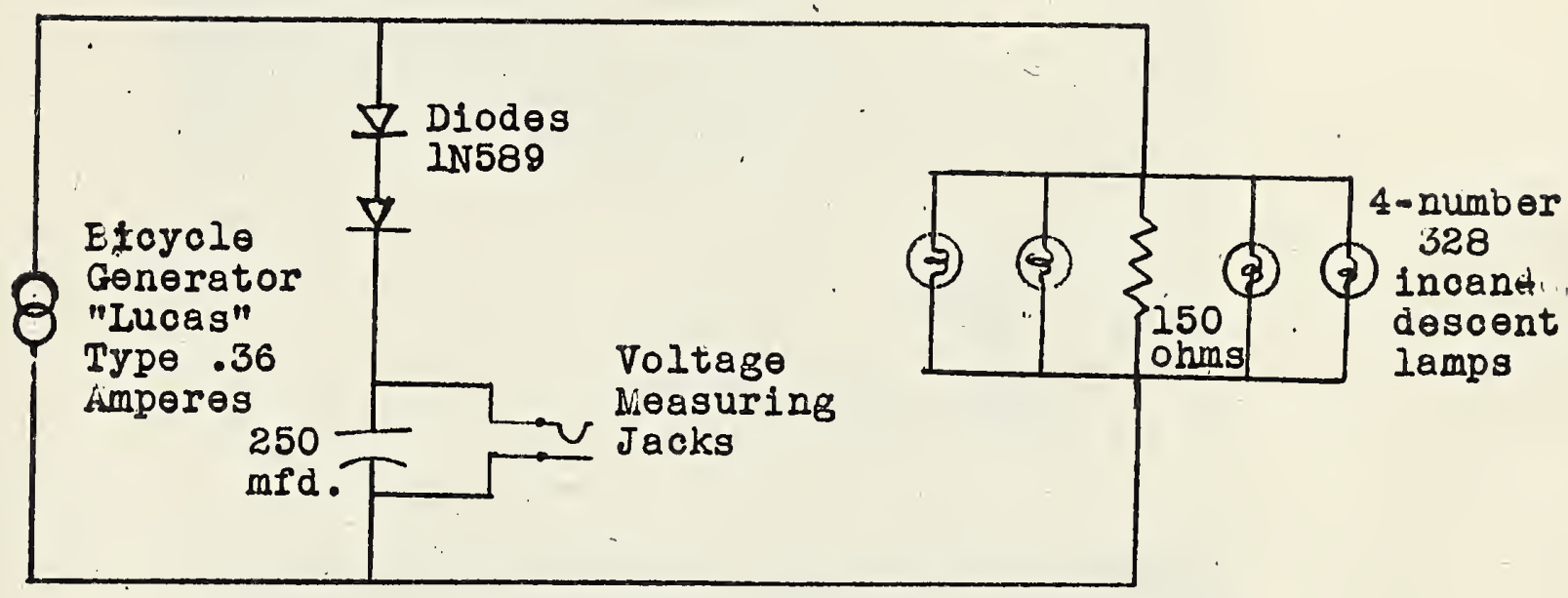

\section{Circuit Operation.}

During flight the voltage developed by the generator is impressed across the lamp load as well as the two diodes and series capacitor. The rectirled voltage through the diodes charges the capacitor to peak voltage. The capacitor remains charged for several hours after the drogue has been retracted from the wind stream but the charge slowly leaks off through the high inverse resistance of the diodes and the dielectric of the capacitor. From previous calibration of voltage leakage versus time, and knowing the elapse time between retraction of the drogue and time of measurement of the remeining voltage in the capacitor, the maximum voltage attained in flight can be computed. The voltage measurement should be made with a VTVM to elininate discharging the capacitor through the voltmeter. 


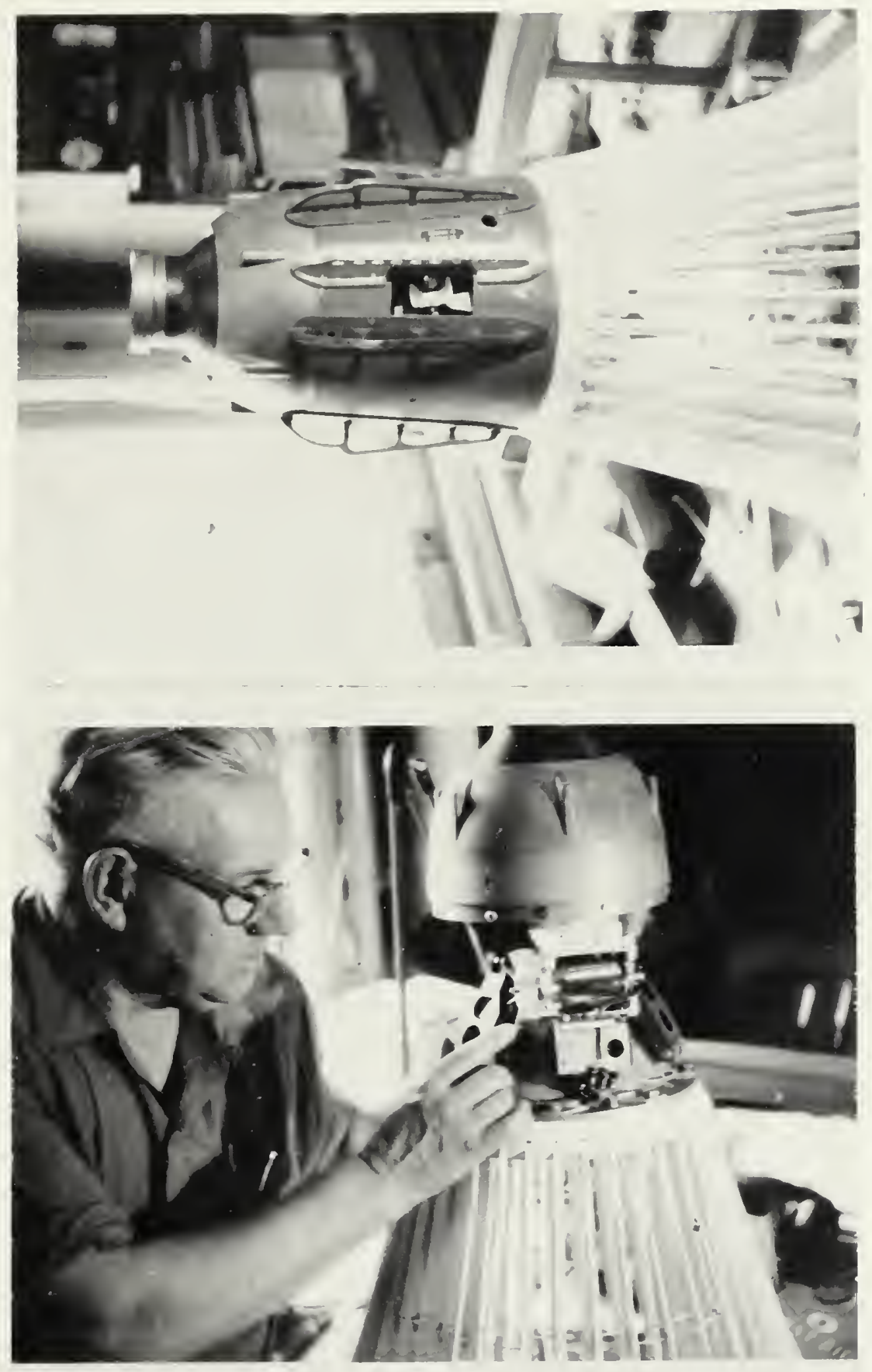

NBS Report 6554

Figure 7 



\section{'THE NA'TIONAL BUREAU OF S'IANDARDS}

The scope of activities of the National IBnrean of Standards at its major laboratories in Waslington, 1).C., and Boulder, Coloralo, is suggested in the following listing of the divisions und sertions congaged in torelunical work. In general, eacls section carries out specialized researel, development, and engiuceriug in the fietel indieated by its title. A brief alescription of the activities, anel of the resultant publerations, appears on the inside of the front cover.

\section{WASHINGTON, D.C.}

Electricity and Elcctronics. Resistance and Reactance. Lilectron Devices. lilectrical Instrunneuts. Mag. netic Mcasurements. Diclectrics. Enginecring Electronics. Eilectronic: Instrunentation. lilectrocheuistry.

Optics and Metrology. Photometry and Colorimetry. Photographic 'Terlonology. Is:ngtlı. lingincering Metrology.

Heat. Temperaturc Physics. Thermorlynamics. Cryogenic Physics. Rlıcology. Molecular Kinctics. Free Radicals Rescarch.

Atomic and Radiation Physics. Spectroscopy. Radiometry. Mass Spectrometry. Solid State: Pliysirs. Elestron Physics. Atomic Physirs. Neutron Physies. Radiation Theory. Radioartivity. X-rays. Iliglı Energy Radiation. Nuclconic Instrumentation. Radiologieal Equipunent.

Chemistry. Organic Coatings. Surfacc Chemistry. Organic Chemistry. Analytical Cheınistry. Inorganic Chemistry. Electrodeposition. Molecular Structure and Properties of Gases. Pliysicul Glucinistry. Therino. chemistry. Spectrochemistry. Pure Substanccs.

Mechanics. Sound. Mechanical Instruments. Fluid Mechanics. lingincering Mechanics. Mass and Seale. Capacity, Density, and Fluid Metcrs. Combustion Controls.

Organic and Fibrous Materials. Rubber. Textiles. Paper. Leatler. Testing and Specifieations. Poly. mer Structure. Plastics: Dental Rescarch.

Metallurgy. Thermal Metallurgy. Chemical Metallurgy. Mechanical Metullurgy. Corrosion. Mctal Pliysics.

Mincral Products. Enginecring Ccramics. Glass. Refractories. linameled Metals. Coustitution and Mi. crostructurc.

Building Technology. Struetural linginecring. Fire Protection. Air Conditioning, Ileating, and Refrigera * tion. Floor, Ros), and Wall Coveringm. Codes and Safety Standarls. Ileat Transfer. Coucreting Materials.

Applied Mathematies. Nunerical Analysis. Computation. Statistical liaginecring. Mathematical Playsics.

Data Processing Systems. SliAC linginecring Group. Couponents and 'Texlıni(ues. Digital Circuitry. Digital Systems. Analog Systcms. Application lingincering.

- Office of Basic Instrumentation.

- Oflice of Weiglits and Measures.

\section{BOULDER, COLORADO}

Cryogenio Enginecring. Cryogenie liquipment. Cryogenie Processes. Propertien of Materials. (Gas Iiquefaction.

Radio Propagation Physics. Upper Atmosplece Rescarelı. Rouonplecrie: Researelı. Ragular Propagation Servicc.. Sun-liarth Relationships. VIIF Researcla, Radio Warning Servieren. Airglow and Aurora. Raulio Astronomy and Aretic l'ropagation.

Radio Propagation Enginecring. Data Redustion Instrumentation. Modulation Researcla. Radio Noise.

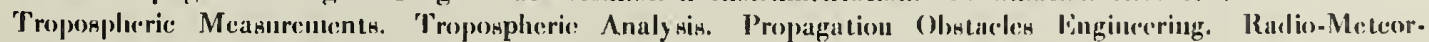
ology. Inwer A tuosphere I'lıysic:s.

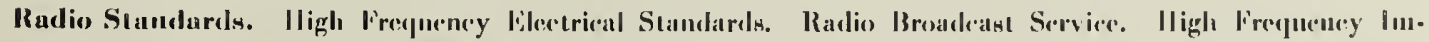

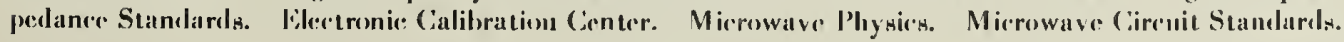

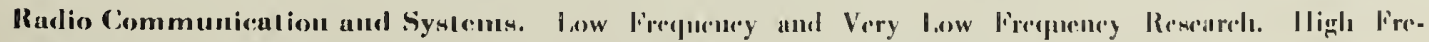

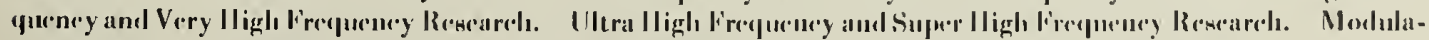

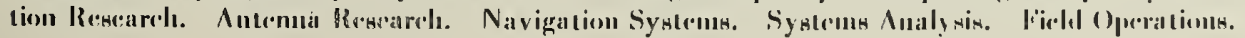


